\title{
FENOMENA PERUBAHAN PENGGUNAAN LAHAN PERTANIAN MENJADI PERUMAHAN: STUDI KASUS KAWASAN PERI-URBAN KECAMATAN COLOMADU
}

Aditya Chrisma Pradana1, Soedwiwahjono1, Kuswanto Nurhadi²

${ }^{1}$ Program Studi Perencanaan Wilayah dan Kota, Fakultas Teknik, Universitas Sebelas Maret

2Program Studi Teknik Sipil, Fakultas Teknik, Universitas Sebelas Maret

\begin{abstract}
Abstrak
Kecamatan Colomadu, Kabupaten Karanganyar merupakan salah satu kawasan pinggiran atau peri urban dari Kota Surakarta. Laju pertumbuhan penduduk Kota Surakarta yang selalu meningkat mengakibatkan pemenuhan kebutuhan termpat tinggal merambat ke kawasan pinggiran kota contohnya di Kecamatan Colomadu. Kecamatan Colomadu mengalami perkembangan yang cukup pesat terutama dari segi fisik kota. Menurut data Badan Pusat Statistik (2013, 2018), Kecamatan Colomadu mengalami penurunan luas penggunaan lahan pertanian sebesar 62,52 Ha antara tahun 2012 hingga 2017. Lalu pada tahun 2012, luas lahan pertanian di Provinsi Jawa Tengah berkurang seluas $300.000 \mathrm{Ha}$ akibat alih fungsi lahan dan Kecamatan Colomadu mengalami alih fungsi lahan tertinggi di Kabupaten Karanganyar. Penelitian ini bertujuan untuk memahami proses perubahan penggunaan lahan pertanian menjadi perumahan di kawasan peri urban Kecamatan Colomadu. Penelitian ini menggunakan pendekatan deduktif serta teknik analisis statistik deskriptif. Penilaian setiap jawaban dari responden dihitung menggunakan rumus deskriptif persentase. Data dalam penelitian diperoleh melalui wawancara kepada warga yang telah menjual lahan pertaniannya kepada pihak pengembang atau developer. Hasil penelitian menunjukan bahwa faktor yang mempengaruhi penjualan lahan pertanian tersebut adalah harga lahan pertanian, status lahan yang merupakan tanah warisan, besarnya kebutuhan/pengeluaran, pendapatan dari hasil pertanian dan profesi di luar sektor pertanian. Sedangkan dari sisi pemilihan lokasi perumahan, konversi lahan pertanian dipengaruhi oleh aksesibilitas, fasilitas sosial ekonomi, lingkungan dan harga lahan.
\end{abstract}

Kata kunci: guna lahan; peri urban; pertanian; perumahan

\begin{abstract}
Colomadu District, Karanganyar Regency is one of the suburban or peri-urban areas in the city of Surakarta. The growth rate of population in Surakarta City has resulted in the spread of urban activities to the surrounding district like Colomadu District. There is a quite rapid development, especially in terms of physical growth in Colomadu District. Data from Central Bureau of Statistics shows that there are 62,52 Hectares of decrease in agricultural land between 2012 and 2017 in Colomadu District. In 2012, the agricultural land in Central Java was reduced by 300.000 Hectares due to land conversion and Colomadu District experienced the highest percentage of land conversion in Karanganyar regency. This research aims to understand factors affecting the land conversion process particularly from agricultural to housing use in the peri-urban area of Colomadu district. Method applied is a deductive approach with statistical descriptive analysis techniques by scoring each response from the respondents that then is calculated using percentage descriptive formula. The data in this research was obtained through interviews to residences who had sold their agricultural land and to developers that bought the land. The result indicates that the factors affecting the the sale of agricultural land are price of agricultural land, inheritance status of the land, expenditure, income from agricultural products compared to income of other professions outside the agricultural sector. Whereas, the developers select certain areas of agricultural land because of its accessibility, socio-economic facility, environment and land prices.
\end{abstract}

Keywords: agricultural; housing; land use; peri urban

\section{PENDAHULUAN}

Pertambahan penduduk yang sangat cepat akan berdampak pada meningkatnya kebutuhan ruang untuk memfasilitasi segala kegiatan dan salah satunya diwujudkan dalam bentuk lahan. Dalam memenuhi dan menampung segala macam 
kegiatan diperlukan lahan yang cukup luas, akan tetapi terdapat keterbatasan lahan yang dimiliki suatu kota baik secara fisik dan geografis. Ketersediaan ruang perkotaan bersifat tetap dan terbatas, karena itu peningkatan kebutuhan ruang untuk tempat tinggal dan kedudukan fungsi-fungsi selalu akan mengambil ruang di daerah pinggiran kota (Yunus, 2000). Apabila kota tidak mampu lagi untuk menampung penduduk alternatif wilayah yang bisa ditempati adalah pinggiran kota, disinilah umumnya perubahan lahan sering terjadi.

Menurut Irawan (2005) ada dua hal yang mempengaruhi alih fungsi lahan, yaitu pembangunan kawasan perumahan atau industri dan peningkatan harga lahan. Meningkatnya kebutuhan lahan baik dari sektor perumahan maupun sektor lainnya akan menyebabkan harga lahan semakin mahal dan sulit didapat karena secara administratif luasan suatu kota adalah tetap. Hal itu menyebabkan meningkatnya perkembangan perumahan baru di kawasan pinggiran karena dalam hal harga lebih murah dari pusat kota.

Kurangnya daya tampung perumahan bagi penduduk yang menetap di kota menyebabkan para perancang dan pengatur kota untuk membangun perumahan ataupun lapangan kerja di daerah pinggiran kota. Daerah pinggiran kota juga dikenal sebagai daerah "Peri Urban". Wilayah peri urban ini menentukan peri kehidupan kekotaan karena segala bentuk perkembangan fisikal baru akan terjadi di wilayah ini, sehingga tatanan kehidupan kekotaan akan pada masa yang akan datang sangat ditentukan oleh bentuk, proses, dan dampak perkembangan yang terjadi di wilayah peri urban.

Daerah pinggiran merupakan wilayah yang banyak mengalami perubahan penggunaan lahan. Perubahan penggunaan lahan yang terjadi sebagian besar merupakan penggunaan lahan pertanian menjadi non pertanian yang disebabkan adanya pengaruh perkembangan kota di dekatnya. Alih fungsi lahan dari penggunaan persawahan menjadi non persawahan semakin meningkat dan cenderung terjadi di desa-desa di daerah hinterland yang lahan persawahannya masih tersedia cukup luas (Setiawan dkk., 1997).

Kecamatan Colomadu, Kabupaten Karanganyar merupakan salah satu wilayah peri urban dari Kota Surakarta. Wilayah ini mengalami perkembangan yang pesat terutama dari segi fisik. Perkembangan wilayah yang dilihat dari berbagai sektor tersebut menyebabkan terjadinya perkembangan penduduk akibat ketertarikan penduduk sekitar untuk berpindah ke Kecamatan Colomadu. Peningkatan pembangunan di Kecamatan Colomadu ditandai dengan perubahan penggunaan lahan, khususnya perubahan penggunaan lahan pertanian yang ada untuk permukiman atau perumahan. Kepala Dinas Pengendalian Penduduk dan Keluarga Berencana (DPPKB) Purwanti, juga menjelaskan bahwa laju pertumbuhan di Kota Surakarta saat ini masih mencapai 1,22\% (Sigit, 2019). Hal ini mengindikasikan bahwa kebutuhan akan tempat tinggal atau perumahan baru meningkat dan pemenuhan kebutuhan tempat tinggal ini akan merambat ke kawasan pinggiran kota contohnya di Kecamatan Colomadu. Menurut data dari Badan Pusat Statistik (2013, 2018), Kecamatan Colomadu mengalami penurunan luas penggunaan lahan pertanian sebesar $62,52 \mathrm{Ha}$ sedangkan penggunaan lahan untuk perumahan meningkat sebesar 54,1 Ha dalam kurun waktu antara tahun 2012 hingga 2017. Pada tahun 2012, Bibit Waluyo selaku Gubernur Jawa Tengah saat itu juga mengatakan luas lahan pertanian di Provinsi Jawa Tengah berkurang seluas 300.000 hektare akibat alih fungsi lahan dan di Kabupaten Karanganyar alih fungsi lahan tertinggi di Kecamatan Colomadu (Wicaksono, 2012). Apabila luas lahan pertanian semakin berkurang dikhawatirkan akan menimbulkan suatu masalah seperti berkurangnya pasokan pangan di wilayah Provinsi Jawa Tengah dan sekitarnya.

Berdasarkan penjabaran tersebut, dapat diketahui bahwa kawasan peri urban Kecamatan Colomadu telah mengalami perubahan penggunaan lahan pertanian menjadi non pertanian khususnya perumahan. Jika perubahan penggunaan lahan pertanian menjadi perumahan yang terjadi terbilang besar, maka diperlukan pengkajian lebih dalam mengenai faktor-faktor yang mempengaruhi perubahan penggunaan lahan pertanian menjadi perumahan di kawasan peri urban Kecamatan Colomadu. Penelitian ini bertujuan untuk mengetahui faktor-faktor yang mempengaruhi perubahan penggunaan lahan pertanian menjadi perumahan di kawasan peri urban Kecamatan Colomadu.

\section{KAJIAN PUSTAKA}

\subsection{PERUBAHAN PENGGUNAAN LAHAN}

Perubahan penggunaan lahan pada dasarnya adalah peralihan fungsi lahan yang tadinya untuk peruntukan tertentu berubah menjadi peruntukan tertentu pula. Wadji Kamal (1987) dalam Wulandari (2017) menjelaskan pengertian perubahan 
penggunaan lahan adalah perubahan penggunaan lahan dari fungsi tertentu menjadi fungsi lainnya, misalnya dari sawah berubah menjadi pemukiman atau tempat usaha. Pengertian tersebut didukung oleh Lestari (2009) yang menjelaskan perubahan penggunaan lahan adalah perubahan fungsi sebagain atau seluruh lahan dari fungsi semula menjadi fungsi lain yang menjadi dampak negatif terhadap lingkungan dan potensi lahan itu sendiri.

\subsection{WILAYAH PERI URBAN}

Perkembangan kota ke daerah pinggiran yang merupakan dampak dari keterbatasan lahan dan eksistensi aktivitas pedesaan menimbulkan perkembangan wilayah peri urban. Kawasan peri urban merupakan zona transisi kota dengan kawasan yang didominasi lahan pertanian. Kawasan ini adalah percampuran penggunaan lahan dan kerancuan batas dalam dan luar serta umumnya merupakan gabungan dari beberapa kawasan yang secara administratif terpisah. Wilayah peri urban terbentuk secara perlahan menjadi sebuah zone yang bertumbuh pesat di pinggiran kota dan tersusun dari berbagai karakteristik penggunaan lahan (Conzen, dalam Rupini dkk, 2017).

Subroto dan Setyadi 1997 dalam Giyarsih (2001) juga menjelaskan bahwa wilayah peri urban (urban fringe) adalah sebagai daerah transisi bukan daerah antara desa dan kota, namun daerah perdesaan yang menyatu dengan daerah perkotaan yang diwarnai oleh disparitas karakter desa dan kota yang kuat baik secara fisik spasial dan sosio kultural. Andreas dalam Budiyantini \& Vidya Pratiwi (2016) menjelaskan, kawasan peri urban adalah zona yang di dalamnya terdapat percampuran antara struktur lahan kedesaan dan lahan kekotaan. Wilayah peri urban adalah daerah rural urban fringe, yaitu wilayah peralihan mengenai penggunaan lahan, karakteristik sosial dan demografis. Wilayah ini terletak antara lahan kekotaan kompak terbangun yang menyatu dengan pusat kota dan lahan kedesaan yang di sana hampir tidak ditemukan bentuk-bentuk lahan kekotaan dan permukiman perkotaan (Pryor, 1968).

\subsection{FAKTOR PENDORONG PENJUALAN LAHAN PERTANIAN}

Salim (1984) dalam Lambok (2016) mengatakan kemampuan petani dalam memenuhi kebutuhannya juga merupakan faktor penentu alih fungsi lahan, petani yang tidak dapat mencukupi pendapatan dalam memenuhi kebutuhan hidup atau pengeluaran yang paling pokok seperti kebutuhan pangan, pakaian, tempat tinggal, kesehatan, pendidikan dan lain-lain atau miskin memiliki kecenderungan untuk melakukan konversi lahan. Kemampuan lahan pertanian dalam menghasilkan komoditi menjadi pertimbangan bagi petani yang mengolahnya. Lahan sawah yang menghasilkan memiliki kecenderungan terhindar dari konversi lahan, dibandingkan dengan lahan yang kemampuan produksinya menurun secara otomatis menurunkan pendapatan dan memiliki kecenderungan untuk dikonversikan menjadi komoditi lain (Wiguna, 2009).

Soegijoko (1997) mengatakan, pendapatan hasil produksi yang semakin lama tidak dapat memenuhi kebutuhan petani dan keluarganya juga menjadi faktor berubahnya lahan pertanian, dapat diartikan nilai tukar hasil usaha pertanian terhadap produk non pertanian semakin menurun. Jika hal tersebut terus berlanjut atau dalam artian nilai tukar hasil pertanian terus menurun maka yang terjadi adalah petani akan memikirkan peluang usaha lain yang dapat menutup pengeluaran akan kebutuhannya. Selain itu, sistem pembagian waris yang sudah menjadi budaya masyarakat Indonesia juga menjadi salah satu faktor berubahnya lahan pertanian menjadi lahan non pertanian. Adanya sistem pembagian waris maka lahan pertanian yang tadinya luas akan terbagi-bagi dan menjadi beberapa petak lahan yang sempit. Jika semua lahan yang sudah terbagi tersebut tetap menjadi lahan pertanian tentunya hal tersebut tidak akan mempengaruhi perubahan penggunaan lahan pertanian menjadi non pertanian, akan tetapi dalam realitanya lebih banyak lahan hasil pembagian waris tersebut yang dialihfungsikan menjadi lahan non pertanian contohnya menjadi rumah atau perumahan. Lahan pertanian yang tadinya luas menjadi sempit dan bahkan tidak ada sama sekali setelah adanya pembagian waris. Sajogyo (1992) mendukung hal tersebut, ia mengatakan kepemilikan lahan pertanian yang kecil disebabkan karena adanya pembagian tanah yang tidak merata. Tekanan penduduk atas tanah yang berat serta terbatasnya kesempatan kerja merupakan pendorong yang kuat bagi petani untuk mencari pekerjaan lain karena hasil yang diperoleh sedikit sehingga pendapatan yang diterima masih kurang untuk memenuhi kebutuhan keluarga.

Swastha \& Irawan (2008) berpendapat, konversi lahan pertanian pada dasarnya terjadi akibat adanya persaingan dalam pemanfaatan lahan antara sektor pertanian dan sektor non pertanian pertumbuhan ekonomi yang cenderung mendorong permintaan lahan untuk kegiatan non pertanian pada laju lebih tinggi dibanding permintaan lahan untuk kegiatan pertanian 
karena permintaan produk non pertanian lebih elastis terhadap pendapatan. Maka dengan meningkatnya permintaan lahan yang relatif tinggi untuk kegiatan non pertanian (akibat pertumbuhan ekonomi) pada akhirnya akan menyebabkan terjadinya konversi lahan pertanian. Irawan juga mengatakan sebagian besar lahan pertanian yang berupa sawah, tegalan atau kebun dimiliki oleh petani. Oleh karena itu proses konversi lahan pertanian umumnya diawali dengan transaksi penjualan lahan petani kepada pihak lain yang umumnya kepada pihak swasta sebagai pengembang (developer) perumahan. Penawaran lahan pertanian tersebut didorong oleh dua fenomena yaitu berlakunya sistem pewarisan lahan yang berdampak pada kepemilikan lahan petani semakin sempit dan penurunan usaha pertanian sebagai konsekuensi dari penurunan sekuler nilai tukar pertanian dan naiknya harga lahan. Kedua fenomena tersebut selanjutnya mendorong petani untuk menjual lahannya dan beralih ke sektor lain karena pendapatan yang diperoleh dari lahan yang dimiliki dinilai tidak mencukupi kebutuhan rumah tangga petani. Berdasarkan teori yang digunakan dapat disimpulkan faktor pendorong penjualan lahan pertanian antara lain lahan sempit akibat dari sistem pewarisan lahan, pengeluaran pemilik lahan yang terus meningkat dan sulit terpenuhi, pendapatan hasil pertanian, profesi diluar sektor pertanian dan harga lahan pertanian.

\subsection{FAKTOR PENDORONG PEMILIHAN LOKASI PERUMAHAN DI KAWASAN PERI URBAN}

Menurut Yunus (1981), gerakan penduduk yang terbalik yaitu dari kota ke daerah pinggiran atau pedesaan untuk memiliki lahan sebagai tempat tinggal semakin meningkat. Hal tersebut disebabkan oleh nilai lahan di daerah pinggiran kota atau pedesaan masih sangat rendah. Masih rendahnya harga tanah di daerah pinggiran kota menjadi alasan para pengembang atau developer membeli luas tanah yang ideal dengan tujuan dijadikan perumahan. Para pengembang atau developer dapat membeli tanah dengan luas tanah yang lebih luas dibandingkan di daerah pusat kota dengan harga yang sama. Adanya pusatpusat pendidikan yang cenderung mengambil lokasi di daerah pinggiran kota memiliki pengaruh yang besar bagi terciptanya perubahan penggunaan lahan agraris menjadi tata guna lahan non agraris. Para pencari tempat tinggal dari suatu wilayah akan mencari lokasi tempat tinggal yang dekat dengan pusat pendidikan, hal itu berlaku juga di wilayah peri urban. la juga menambahkan bahwa penduduk akan mencari lokasi tempat tinggal yang berdekatan dengan pekerjaannya atau bisa dibilang dekat dengan tempat kegiatan ekonominya.

Dasra (1995) dalam Saputra (2016) mengatakan bahwa faktor-faktor dominan dalam penentuan lokasi perumahan, yaitu arah perkembangan kota, ketersediaan lahan dan harga tanah, kondisi sosial budaya, aksesibilitas, transportasi, dan utilitas. Turner (1976) dalam Rindarjono (2007) menyatakan, pemilihan perumahan di pinggiran kota juga karena adanya penyebaran jalur transportasi yang dapat memudahkan pergerakan manusia. Penduduk yang berada di wilayah pinggiran kota dapat menggunakan sarana transportasi berupa bus dan angkutan umum yang melintasi sepanjang jalan dari pinggiran kota hingga ke pusat kota.

Menurut Wardana (2007), aksesibilitas yang baik di wilayah pinggiran kota menjadi salah satu penarik untuk mendatangkan penduduk dan mempermudah penduduk dalam pergerakannya. Hal tersebut sesuai dengan Chapin \& Kaiser (1979) yang mengatakan, kegiatan penentuan lokasi perumahan seharusnya juga mempertimbangkan berbagai faktor pendukung seperti ekonomi, guna lahan, transportasi, dan kemasyarakatan. Kemasyarakatan yang dimaksud adalah kondisi lingkungan sosial yang dapat mempengaruhi kenyamanan seseorang dalam bertempat tinggal di suatu wilayah.

Drabkin (1980) dalam Kalesaran (2013) mengemukakan, faktor yang berpengaruh terhadap pemilihan lokasi perumahan, yaitu aksesibilitas, lingkungan, kesempatan kerja yang tersedia, dan tingkat pelayanan. Faktor aksesibilitas ini terdiri dari kemudahan transportasi dan jarak ke pusat kota. Faktor lingkungan dalam hal ini terdiri dari lingkungan sosial dan fisik seperti kebisingan, polusi dan kenyamanan lingkungan. Kemudian faktor kesempatan kerja yang tersedia, yaitu kemudahan seseorang dalam mendapatkan pekerjaan untuk keberlangsungan hidupnya. Selanjutnya, faktor tingkat pelayanan lokasi yang dipilih merupakan lokasi yang memiliki pelayanan yang baik dalam hal sarana dan prasarana. Selain itu baru ada faktor rasa keamanan dan lingkungan perumahan yang rendah kebisingannya. Berdasarkan teori yang digunakan dapat disimpulkan faktor pendorong pemilihan lokasi perumahan antara lain harga lahan, fasilitas sosial ekonomi, aksesibilitas dan lingkungan.

\section{METODE PENELITIAN}

Pendekatan penelitian yang digunakan dalam penelitian ini yaitu pendekatan deduktif. Tahap awal yang dilakukan ialah menggali isu-isu yang ada di wilayah peri urban Kecamatan Colomadu mengenai perubahan penggunaan lahan pertanian 
menjadi perumahan, kemudian melakukan eksplorasi teori mengenai faktor pendorong penjualan lahan pertanian dan faktor pendorong pemilihan lokasi perumahan di kawasan peri urban. Ruang lingkup wilayah studi dalam penelitian ini ialah kawasan peri urban Kecamatan Colomadu keseluruhan secara administratif (Gambar 1).

Substansi yang akan dibahas dalam penelitian ini adalah faktor-faktor yang mempengaruhi perubahan penggunaan pertanian menjadi perumahan dilihat dari faktor pendorong penjualan lahan pertanian dan faktor pendorong pemilihan lokasi perumahan di kawasan peri urban dengan menggunakan data yang didapatkan dari wawancara kepada pemilik lahan pertanian dan pihak pengembang atau developer. Kriteria yang akan dibahas dalam penelitian ini yaitu lahan sempit dari sistem pewarisan, pengeluaran, pendapatan hasil pertanian, profesi di luar sektor pertanian, harga lahan pertanian, aksesibilitas, fasilitas sosial ekonomi dan lingkungan.

Data yang diperlukan diperoleh menggunakan teknik pengumpulan data primer yang dilakukan melalui wawancara kepada warga atau masyarakat yang telah menjual lahan pertanian miliknya dan pihak pengembang atau developer yang telah mengembangkan atau membangun perumahan di Kecamatan Colomadu. Selanjutnya data akan dianalisis secara kuantitatif, yaitu penilaian masing-masing variabel jawaban berdasarkan jumlah jawaban dari setiap responden dan dilakukan perhitungan menggunakan teknik analisis statistik deskriptif untuk mengetahui faktor-faktor yang mempengaruhi perubahan penggunaan lahan pertanian menjadi perumahan di kawasan peri urban Kecamatan Colomadu. Tabel 1 merupakan variabel dan penilaian masing-masing variabel berdasarkan jumlah jawaban dari setiap responden yang digunakan dalam penelitian ini (Tabel 1).
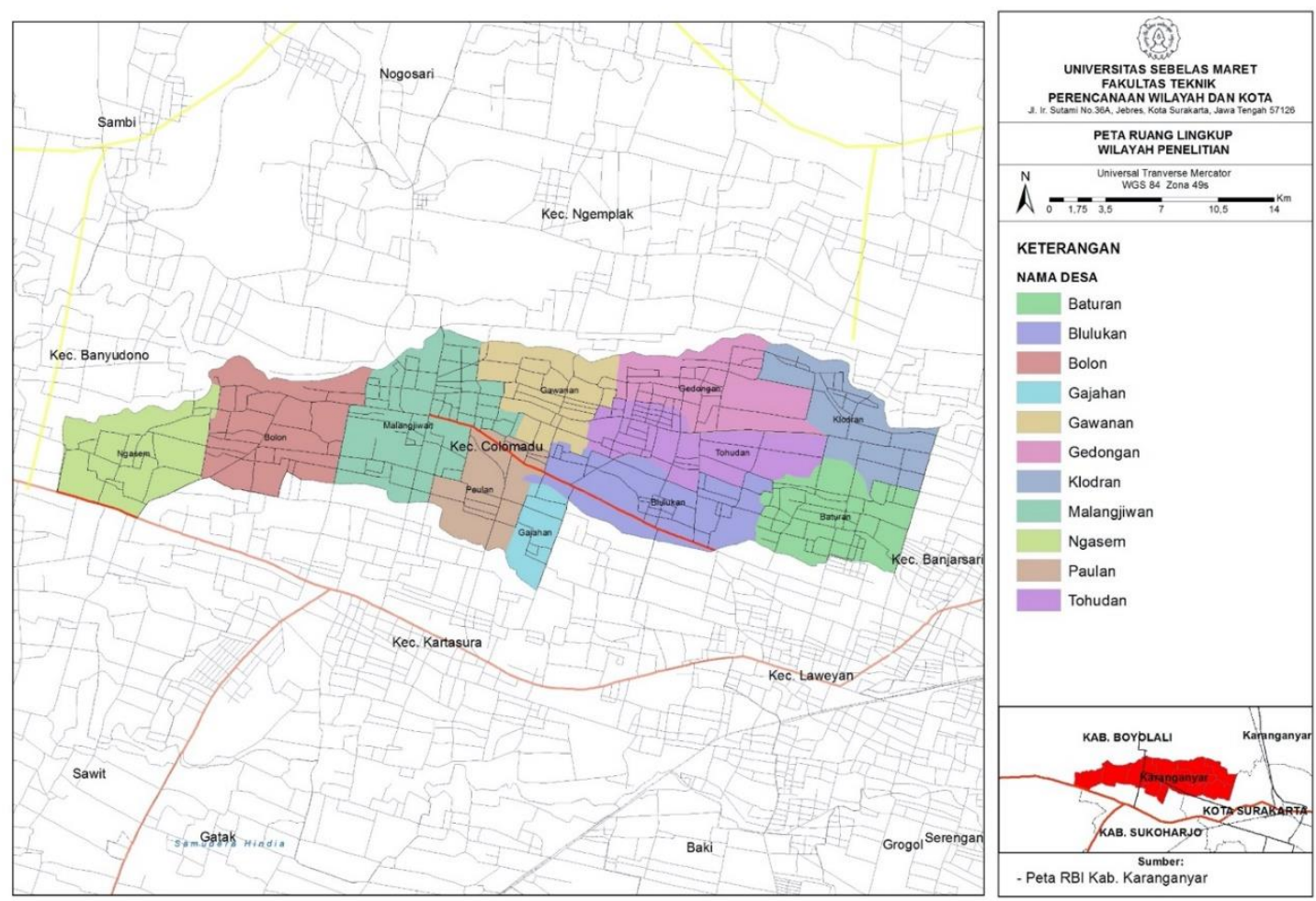

\section{Gambar 1. Peta Ruang Lingkup Wilayah Penelitian}

Variabel dalam penelitian ini dikelompokan menjadi 2, yaitu faktor pendorong penjualan lahan pertanian yang terdiri dari lahan sempit dari sistem pewarisan, pengeluaran, pendapatan hasil pertanian, profesi di luar sektor pertanian dan harga lahan pertanian. Selanjutnya, faktor pendorong pemilihan lokasi perumahan di kawasan peri urban yang terdiri dari harga lahan, fasilitas sosial ekonomi, aksesibilitas dan lingkungan. Setiap faktor yang dipilih oleh responden akan memperoleh nilai skor yang disesuaikan dengan jumlah jawaban dari setiap responden. Setiap responden memiliki nilai skor total sebesar 5. 
Tabel 1. Variabel dan skor berdasarkan jumlah jawaban responden

\begin{tabular}{lccccc}
\hline \multirow{2}{*}{ Variabel } & \multicolumn{5}{c}{ Skor berdasarkan Jumlah Jawaban Responden } \\
\cline { 2 - 7 } & $\begin{array}{l}\text { 1 Faktor } \\
\text { Jawaban }\end{array}$ & $\begin{array}{c}\text { 2 Faktor } \\
\text { Jawaban }\end{array}$ & $\begin{array}{c}\text { 3 Faktor } \\
\text { Jawaban }\end{array}$ & $\begin{array}{c}\text { 4 Faktor } \\
\text { Jawaban }\end{array}$ & $\begin{array}{c}\text { 5 Faktor } \\
\text { Jawaban }\end{array}$ \\
\hline Faktor Pendorong Penjualan Lahan Pertanian & & & & & \\
Lahan Sempit dari Warisan & 5 & 2,5 & 1,6 & 1,25 & 1 \\
Pengeluaran & 5 & 2,5 & 1,6 & 1,25 & 1 \\
Pendapatan Hasil Pertanian & 5 & 2,5 & 1,6 & 1,25 & 1 \\
Profesi di Luar Sektor Pertanian & 5 & 2,5 & 1,6 & 1,25 & 1 \\
Harga Lahan Pertanian & 5 & 2,5 & 1,6 & 1,25 & 1 \\
\hline Faktor Pendorong Pemilihan Lokasi Perumahan & di Kawasan & Peri Urban & & & \\
Harga Lahan & 5 & 2,5 & 1,6 & 1,25 & 1 \\
Fasilitas Sosial Ekonomi & 5 & 2,5 & 1,6 & 1,25 & 1 \\
Aksesibilitas & 5 & 2,5 & 1,6 & 1,25 & 1 \\
Lingkungan & 5 & 2,5 & 1,6 & 1,25 & 1 \\
\hline
\end{tabular}

Hasil penilaian masing-masing jawaban dari setiap responden yang telah dijumlah kemudian dihitung menggunakan rumus deskriptif persentase sebagai berikut:

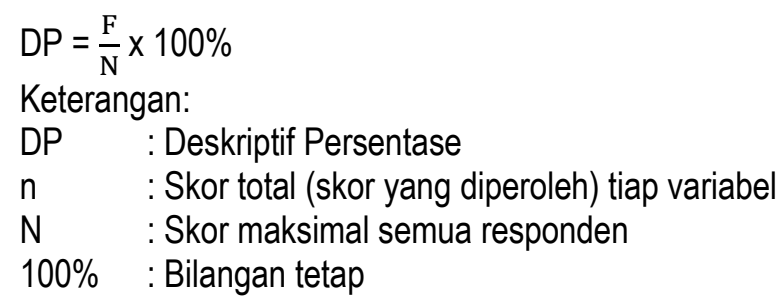

Dari perhitungan menggunakan rumus di atas maka akan didapatkan faktor tertinggi dan terendah dari faktor pendorong penjualan pertanian dan faktor pendorong pemilihan lokasi di kawasan peri urban. Berdasarkan hasil tersebut, dilakukan pembahasan atau penjabaran dari semua faktor sehingga dapat diketahui faktor-faktor yang mempengaruhi perubahan penggunaan lahan pertanian menjadi perumahan.

\section{HASIL DAN PEMBAHASAN}

\subsection{FAKTOR PENDORONG PENJUALAN LAHAN PERTANIAN}

Terdapat beberapa faktor yang menjadi pendorong warga atau masyarakat dalam menjual lahan pertanian miliknya yaitu lahan sempit dari warisan, pengeluaran, pendapatan hasil pertanian, profesi di luar sektor pertanian dan harga lahan.

\subsubsection{Lahan Sempit dari Warisan}

Pada kawasan peri urban Kecamatan Colomadu, faktor lahan sempit dari warisan menjadi pendorong warga atau masyarakat untuk menjual lahan pertaniannya dengan tingkat persentase sebesar $25 \%$. Warga atau masyarakat menjual lahan pertanian yang dimilikinya dengan alasan lahan pertanian yang dimilikinya apabila dibagikan ke anak-anaknya atau ahli warisnya masing-masing akan mendapatkan lahan yang sangat sempit. Keadaan tersebut membuat para warga atau masyarakat memilih menjual lahan pertanian miliknya, lalu hasil dari penjualan lahan pertanian tersebut baru dibagikan ke para ahli warisnya.

Selain membagikan hasil penjualan lahan pertanian, mereka juga memilih membeli lahan di daerah lain dari hasil penjualan lahan pertaniannya. Mereka membeli lahan yang harganya jauh lebih rendah untuk diwariskan. Oleh karena harga yang lebih rendah tersebut, mereka akan mendapatkan lahan yang lebih luas dengan harga yang sama dengan hasil penjualan lahan pertanian sebelumnya. 


\subsubsection{Pengeluaran}

Pada kawasan peri urban Kecamatan Colomadu, faktor pengeluaran menjadi pendorong warga atau masyarakat untuk menjual lahan pertaniannya dengan tingkat persentase sebesar $16 \%$. Warga atau masyarakat menjual lahan pertaniannya karena pendapatan dari lahan pertaniannya tidak lagi dapat mencukupi kebutuhan hidupnya beserta keluarga. Kebutuhan hidup yang kian meningkat dan pendapatan dari lahan pertanian yang tetap sama atau cenderung menurun, mendorong para pemilik lahan pertanian untuk beralih profesi dan akhirnya menjual lahan pertaniannya.

Selain itu, adanya pengeluaran yang mendadak seperti pengobatan dan pengeluaran yang direncanakan seperti biaya pendidikan, dengan keadaan ekonomi atau tabungan yang tidak dapat memenuhi pengeluaran tersebut, para pemilik lahan pertanian memilih menjual lahan pertanian yang dimilikinya karena hanya dengan hal tersebut mereka bisa mendapatkan dana yang relatif besar dan cepat untuk memenuhi kebutuhan atau pengeluarannya.

\subsubsection{Pendapatan Hasil Produksi}

Pada kawasan peri urban Kecamatan Colomadu, faktor pendapatan hasil produksi menjadi pendorong warga atau masyarakat untuk menjual lahan pertaniannya dengan tingkat persentase sebesar $11 \%$. Warga atau masyarakat memilih menjual lahan pertaniannya dikarenakan lahan yang sudah tidak profuktif atau dalam kata lain pendapatan dari hasil pertanian yang menurun. Beberapa responden menjelaskan hal ini terjadi karena harga komoditi pertanian yang tidak stabil dan cenderung menurun. Nilai hasil pertanian yang stabil dan cenderung menurun tersebut tidak sebanding dengan nilai kebutuhan hidup yang selalu meningkat kian waktu. Pada akhirnya mereka memilih menjual lahan tersebut dan hasilnya dialihkan ke usaha lain.

Selain itu, lahan pertanian yang sudah mati atau tidak bisa digarap lagi juga menjadi alasan mereka menjual lahan pertaniannya. Kondisi lahan yang tidak baik, seperti sudah tidak subur atau tandus dan sitem pengairan yang sudah tidak berjalan dengan baik menyebabkan tidak ada ingin menggarap atau mengolah lahan pertaniannya. Mereka memutuskan menjual lahan pertanian tersebut karena lahan tersebut tidak bisa mereka olah lagi dan tidak memberikan pendapatan untuk mereka karena apabila lahan tersebut masih produktif maka mereka akan mendapatkan pendapatan salah satunya dari biaya sewa penggarap sawah.

\subsubsection{Profesi di Luar Sektor Petanian}

Pada kawasan peri urban Kecamatan Colomadu, faktor profesi di luar sektor pertanian menjadi pendorong warga atau masyarakat untuk menjual lahan pertaniannya dengan tingkat persentase sebesar $11 \%$. Warga atau masyarakat memilih menjual lahan pertaniannya dikarenakan sudah memiliki pekerjaan atau profesi lain di luar sektor pertanian seperti toko atau jasa lainnya. Pendapatan dari lahan pertanian yang terus menurun mendorong mereka menjual lahan pertaniannya dengan tujuan untuk mengembangkan usahanya dari hasil penjualan lahan pertanian tersebut.

Selain itu, mereka juga memilih menjual lahan pertaniannya karena memiliki keinginan untuk beralih profesi selain sektor pertanian. Lahan pertanian yang dimiliki dijual sebagai modal untuk membangun usaha atau profesi yang diinginkannya. Mereka beranggapan pekerjaan atau profesi di sektor pertanian sudah tidak menjanjikan untuk memenuhi segala kebutuhan dan pengeluarannya. Akan tetapi, tidak semua hasil penjualan lahan pertanian mereka jadikan modal untuk mengembangkan atau memulai pekerjaanya, hasil dari penjualan lahan pertanian juga mereka belikan lahan di daerah lain yang memiliki harga lebih rendah.

\subsubsection{Harga Lahan Pertanian}

Pada kawasan peri urban Kecamatan Colomadu, faktor harga lahan pertanian menjadi faktor pendorong penjualan lahan pertanian dengan tingkat persentase tertinggi yaitu sebesar 37\% (Gambar 2). Diketahui alasan masyarakat menjual lahan pertaniannya dikarenakan adanya tawaran dari pihak pengembang atau developer perumahan. Pihak pengembang atau developer memberikan tawaran dengan harga tinggi yang membuat para pemilik lahan pertanian tergiur dengan tawaran tersebut. Beberapa pemilik lahan pertanian menjelaskan, pada awalnya mereka tidak tertarik atau tidak ada niatan untuk menjual lahan pertaniannya, tetapi dari pihak pengembang atau developer terus menerus mendatangi untuk membeli lahan 
pertaniannya. Kondisi tersebut kian hari membuat para pemilik lahan jengah dan pada akhirnya memilih untuk melepaskan lahan pertaniannya, juga karena tawaran harga dari pihak pengembang atau developer yang terus naik. Di beberapa kasus, pihak pengembang atau developer langsung menyetujui harga yang ditawarkan oleh pemilik lahan.

Selain itu, lokasi lahan pertanian di Kecamatan Colomadu yang merupakan lokasi strategis karena dekat dengan berbagai pusat kegiatan membuat lahan tersebut memiliki harga yang tinggi. Harga lahan yang sedang tinggi dan juga lebih tinggi dari daerah di sekitarnya mendorong pemilik lahan pertanian untuk menjual lahan pertaniannya. Hal tersebut dilakukan karena mereka berpikiran hasil dari penjualan lahan tersebut dapat mereka belikan lagi lahan di daerah lain yang lebih luas dan sisanya dapat mereka jadikan tabungan. Luas lahan yang mereka miliki akan tetap atau bertambah dan juga menambah tabungan.

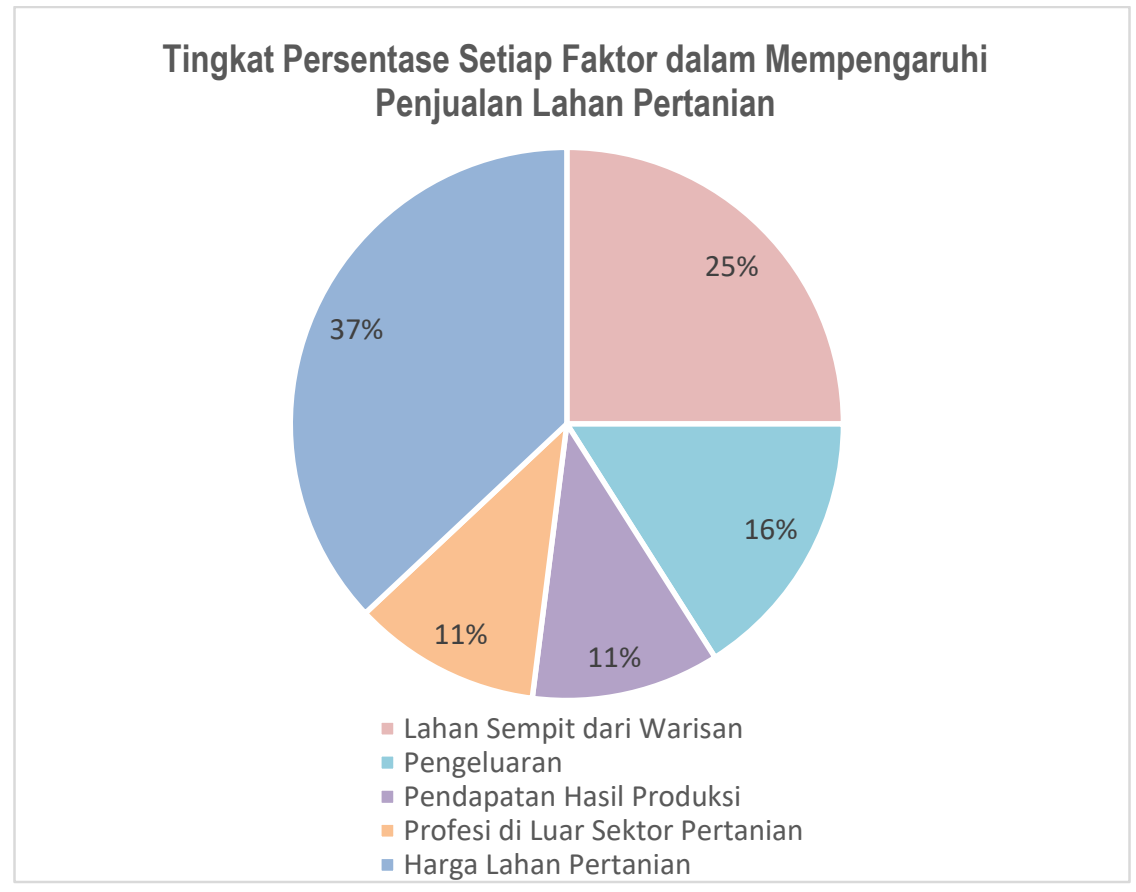

Gambar 2. Diagram Tingkat Persentase Setiap Faktor dalam Mempengaruhi Penjualan Lahan Pertanian

\subsection{FAKTOR PENDORONG PEMILIHAN LOKASI PERUMAHAN DI KAWASAN PERI URBAN}

Terdapat beberapa faktor yang menjadi pendorong pihak pengembang atau developer dalam memilih lokasi perumahan, yaitu harga lahan, fasilitas sosial ekonomi, aksesibilitas dan lingkungan.

\subsubsection{Harga Lahan}

Pada kawasan peri urban Kecamatan Colomadu, faktor harga lahan menjadi pendorong pihak pengembang atau developer memilih lokasi perumahan yang akan dikembangkan atau dibangun dengan tingkat persentase sebesar 0\% (Gambar 3). Hasil wawancara yang dilakukan kepada pihak pengembang atau developer perumahan yang sudah mengembangkan atau membangun perumahan di Kecamatan Colomadu bertolak belakang dengan teori di atas. Berdasarkan 16 responden yang telah diwawancarai, mereka tidak menyebutkan harga lahan sebagai faktor yang mendorong mereka dalam memilih lokasi perumahan di Kecamatan Colomadu. Secara keseluruhan jawaban dari semua responden tidak ada satupun kalimat dari jawaban dan penjelasan responden yang menyinggung soal harga lahan. 


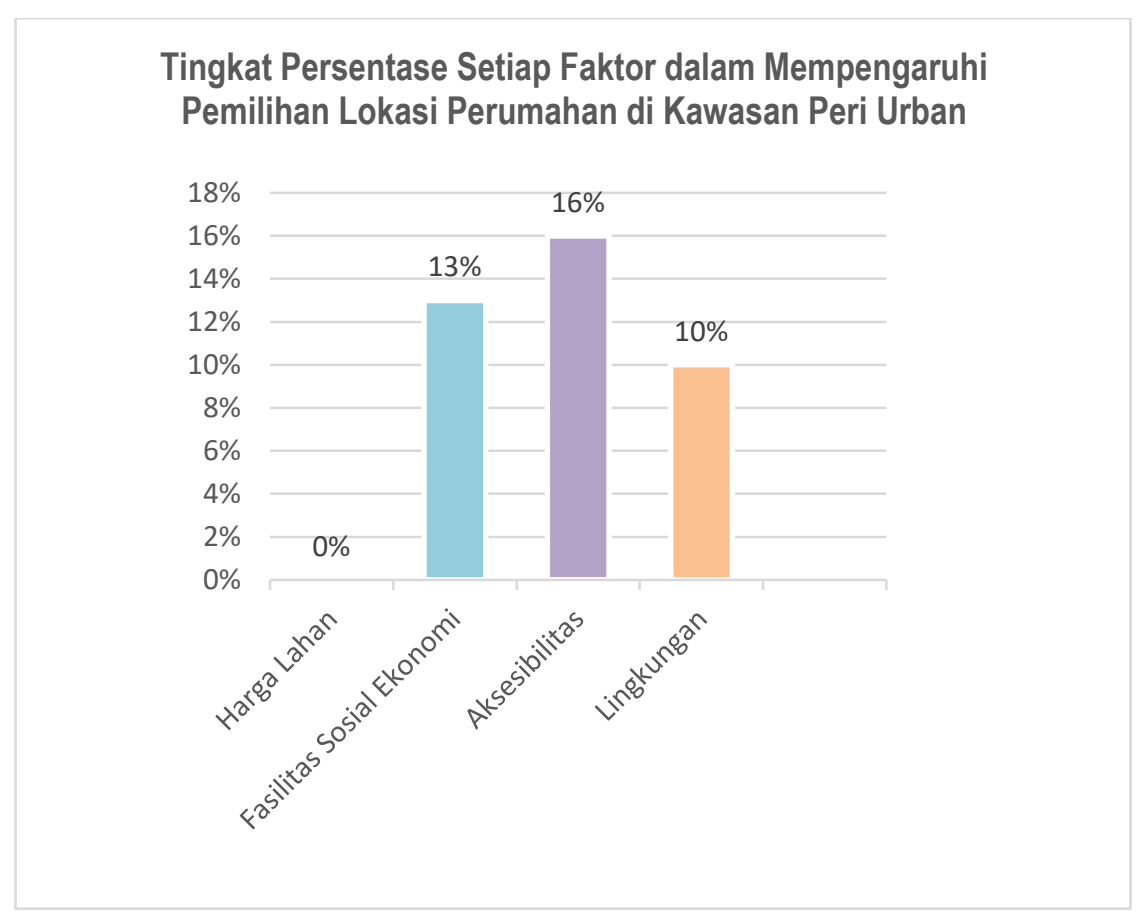

Gambar 3. Diagram Tingkat Persentase Setiap Faktor dalam Mempengaruhi Pemilihan Lokasi Perumahan

\subsubsection{Fasilitas Sosial Ekonomi}

Pada kawasan peri urban Kecamatan Colomadu, faktor fasilitas sosial ekonomi menjadi pendorong pihak pengembang atau developer memilih lokasi perumahan yang akan dikembangkan atau dibangun dengan tingkat persentase sebesar $13 \%$ (Gambar 3). Pada kawasan peri urban Kecamatan Colomadu, pihak pengembang atau developer memilih lokasi perumahan di daerah ini dikarenakan sudah tersedianya fasilitas sosial ekonomi, seperti pendidikan, kesehatan, peribadatan dan perekonomian. Beberapa responden menjelaskan, faktor kedekatan dengan bandara Adi Sumarmo, gerbang toll Solo Kertosono, fasilitas pendidikan yang sudah menyebar dan pusat perbelanjaan menjadi salah satu faktor yang mendorong mereka dalam memilih lokasi perumahan yang akan dikembangkan.

Sudah tersedianya fasilitas sosial ekonomi di Kecamatan Colomadu dapat membantu pihak pengembang atau developer dalam memasarkan perumahan yang dikembangkannya. Ketersediaan dan kedekatan dengan berbagai fasilitas sosial ekonomi menjadi nilai tambah produk perumahan mereka karena calon pembeli akan lebih memilih rumah yang berlokasi dekat dengan berbagai pusat-pusat kegiatan. Pihak pengembang atau developer juga tidak perlu mengeluarkan biaya untuk membangun atau bekerja sama dengan pihak lain untuk menyediakan berbagai fasilitas sosial ekonomi tersebut.

\subsubsection{Aksesibilitas}

Pada kawasan peri urban Kecamatan Colomadu, faktor aksesibilitas menjadi pendorong pihak pengembang atau developer memilih lokasi perumahan yang akan dikembangkan atau dibangun dengan tingkat persentase sebesar 16\% (Gambar 3). Pada kawasan peri urban Kecamatan Colomadu, pihak pengembang atau developer memilih lokasi perumahan di daerah ini dikarenakan kemudahan dalam menuju ke berbagai tempat atau pusat-pusat kegiatan. Kualitas jalan yang sudah beraspal di sebagian besar wilayah di Kecamatan Colomadu juga membantu mereka dalam memasarkan produk perumahannya kelak.

Selain itu, dengan mudahnya mencapai berbagai pusat-pusat kegiatan menjadikan lokasi yang mereka pilih menjadi lokasi strategis. Hal tersebut menjadi nilai tambah produk perumahan mereka karena perumahan yang berada di lokasi strategis 
akan menjadikan produk perumahan yang mereka jual sebagai sebuah investasi yang menjajikan. Mereka menjelaskan, calon pembeli lebih tertarik membeli produk perumahan yang memiliki nilai investasi tinggi.

\subsubsection{Lingkungan}

Pada kawasan peri urban Kecamatan Colomadu, faktor lingkungan menjadi pendorong pihak pengembang atau developer memilih lokasi perumahan yang akan dikembangkan atau dibangun dengan tingkat persentase sebesar 10\% (Gambar 3). Pada kawasan peri urban Kecamatan Colomadu, pihak pengembang atau develover memilih faktor lingkungan sebagai faktor pendorong dalam menentukan lokasi perumahan yang akan dikembangkan atau dibangun. Sebagian responden menjelaskan bahwa kenyamanan, kebersihan, kemanan, kondisi sosial dan bebas banjir menjadi pertanggungjawaban mereka kepada calon pembeli karena mayoritas pembeli akan menanyakan hal seputar lingkungan di dalam maupun di sekitar produk perumahan mereka.

\subsection{FAKTOR-FAKTOR YANG MEMPENGARUHI PERUBAHAN PENGGUNAAN LAHAN PERTANIAN MENJADI PERUMAHAN DI KAWASAN PERI URBAN KECAMATAN COLOMADU}

Faktor-faktor yang mempengaruhi perubahan penggunaan lahan pertanian menjadi perumahan di kawasan peri urban Kecamatan Colomadu didapatkan dengan mengkaji faktor pendorong penjualan lahan pertanian dan faktor pendorong pemilihan lokasi perumahan. Masing-masing faktor saling berkaitan satu sama lain.

Pada faktor pendorong penjualan lahan pertanian, pemilik memulai berpikiran menjual lahan pertaniannya dikarenakan pendapatan hasil pertanian dari lahan miliknya sudah tidak dapat lagi mencukupi berbagai keperluan dan kebutuhan hidup yang selalu meningkat. Pekerjaan di sektor pertanian dirasa tidak dapat mengatasi segala pengeluaran rumah tangganya dan pada akhirnya mereka memilih untuk beralih profesi di luar sektor pertanian.

Selanjutnya pada faktor pendorong pemilihan lokasi perumahan, pihak pengembang atau developer memilih lokasi perumahan di kawasan peri urban Kecamatan Colomadu karena Kecamatan Colomadu dianggap menjadi tempat yang strategis. Kecamatan Colomadu menjadi tempat yang strategis karena lokasinya yang dekat dan dengan mudah menuju ke berbagai pusat kegiatan seperti pusat pendidikan, pusat kesehatan, pusat peribadatan, pusat perekonomian dan pusat perbelanjaan.

Dari keseluruhan faktor pendorong penjualan lahan pertanian dan pendorong pemilihan lokasi perumahan di kawasan peri urban Kecamatan Colomadu didapatkan hasil bahwa pada faktor pendorong penjualan lahan pertanian, faktor yang memiliki tingkat persentase tertinggi adalah faktor harga lahan pertanian yang memiliki tingkat persentase sebesar $37 \%$. Selanjutnya pada faktor pendorong pemilihan lokasi perumahan di kawasan peri urban, faktor yang memiliki tingkat persentase terendah yaitu faktor harga lahan. Hal ini sangat barkaitan karena pada kawasan peri urban Kecamatan Colomadu, pihak pengembang atau developer tidak terlalu mempertimbangkan harga lahan yang akan dibelinya. Mereka menyanggupi semua harga yang diajukan pemilik lahan yang akan dibelinya yang dalam sebagian besar kasus tanpa adanya tawar menawar harga. Dari sudut pemilik lahan, mayoritas melepaskan lahan pertaniannya karena tawaran harga tinggi dari pihak pengembang atau developer dan harga yang mereka ajukan langsung disepakati oleh pihak pengembang atau developer.

Selain itu, juga didapatkan informasi bahwa terdapat beberapa perumahan yang lokasinya tidak sesuai dengan peraturan tata ruang yang berlaku. Beberapa perumahan dibangun di lahan dengan peruntukan sebagai sawah lestari atau di zona hijau (tidak boleh didirikan bangunan). Hal tersebut di luar kendali dari warga atau masyarakat yang telah menjual lahan pertaniannya karena pembeli lahanlah yang berhak menentukan bagaimana lahan tersebut akan digunakan ataupun diolah.

\section{KESIMPULAN}

Faktor-faktor yang mempengaruhi perubahan penggunaan lahan dapat ditinjau dari 2 faktor pendorong, yaitu faktor pendorong penjualan lahan pertanian dan faktor pendorong pemilihan lokasi perumahan di kawasan peri urban. Pada faktor pendorong penjualan lahan pertanian terdapat 5 faktor pendorong, yaitu warisan, pengeluaran, pendapatan hasil pertanian, profesi di luar sektor pertanian dan harga lahan pertanian. Sedangkan, pada faktor pemilihan lokasi perumahan di kawasan peri urban terdapat 4 faktor pendorong, yaitu harga lahan, fasilitas sosial ekonomi, aksesibilitas dan lingkungan. 
Berdasarkan analisis yang dilakukan mengenai tingkat persentase masing-masing faktor dalam mempengaruhi penjualan lahan pertanian, didapatkan hasil bahwa faktor harga lahan pertanian memiliki tingkat persentase tertinggi dalam mendorong warga atau masyarakat menjual lahan pertanian miliknya dengan tingkat persentase sebesar $37 \%$. Kemudian faktor warisan sebesar $25 \%$, faktor pengeluaran sebesar $16 \%$, faktor pendapatan hasil pertanian sebesar $11 \%$ dan profesi di luar sektor pertanian sebesar $11 \%$. Selanjutnya dari analisis yang dilakukan mengenai tingkat persentase masing-masing faktor dalam mempengaruhi pemilihan lokasi perumahan di kawasan peri urban, didapatkan hasil bahwa faktor harga lahan memiliki tingkat persentase terendah yaitu sebesar $0 \%$ atau tidak mempengaruhi pihak pengembang atau developer dalam memilih lokasi perumahan di Kecamatan Colomadu. Kemudian faktor lingkungan sebesar 27\%, faktor fasilitas sosial ekonomi sebesar 31\%, dan faktor aksesibilitas sebesar $42 \%$.

Berdasarkan hasil kedua analisis tersebut dapat disimpulkan bahwa faktor harga lahan menjadi faktor yang paling berpengaruh dalam perubahan penggunaan lahan pertanian menjadi perumahan di kawasan peri urban Kecamatan Colomadu. Warga atau masyarakat memilih menjual lahan pertaniannya karena harga yang ditawarkan dari pihak pengembang atau developer lebih tinggi dari harga normal maupun harga lahan di daerah sekitar. Sedangkan dari pihak pengembang atau developer, mereka tidak terlalu mempertimbangkan harga lahan lokasi yang akan dikembangkannya. Mayoritas pihak pengembang atau developer akan menyanggupi besaran harga lahan yang diajukan oleh warga atau masyarakat tanpa adanya proses tawar menawar. Lokasi lahan pertanian yang berada di tempat yang strategis tentunya memiliki aksesibilitas yang baik pula dan harga lahan tersebut akan memiliki nilai jual yang lebih tinggi sehingga para pemilik lahan di kawasan tersebut terdorong untuk menjual lahan miliknya yang hasilnya akan dibelikan lahan pertanian di daerah lain yang lebih murah harganya dan sisanya dijadikan tabungan atau modal usaha lain. Lokasi lahan pertanian yang terletak di tempat strategis dan memiliki aksesibilitas yang baik memberikan daya tarik kepada pihak pengembang atau developer untuk membeli lahan tersebut yang selanjutnya akan dikembangkan atau dibangun sebagai produk perumahan mereka.

Namun dalam perubahan penggunaan lahan pertanian menjadi perumahan yang terjadi diperoleh informasi bahwa ada beberapa perumahan yang dibangun atau dikembangkan di lahan yang berdasarkan peraturan merupakan lahan yang berada pada zona hijau (tidak boleh didirikan bangunan). Diharapkan ada upaya yang dilakukan pemerintah agar lahan pertanian tidak semakin berkurang adalah dengan memperketat peraturan terkait penggunaan lahan dan melakukan pengawasan yang lebih.

\section{DAFTAR PUSTAKA}

Badan Pusat Statistik Kabupaten Karanganyar (2013, November 28). Kabupaten Karanganyar Dalam Angka Tahun 2013. Diakses dari https://karanganyarkab.bps.go.id/publication/2013/11/28/303d33b435daf31787299746/karanganyar-dalam-angka-2013.html

Badan Pusat Statistik Kabupaten Karanganyar (2018, Agustus 16). Kabupaten Karanganyar Dalam Angka Tahun 2018. Diakses dari: https://karanganyarkab.bps.go.id/publication/2018/08/16/5048386581b2868436d40a23/kabupaten-karanganyar-dalam-angka2018.html

Swastha, B., \& Irawan. (2008). Manajemen Pemasaran Modern. Yogyakarta: Liberty.

Budiyantini, Y., \& Pratiwi, P. (2016). Peri-urban typology of Bandung Metropolitan Area. CITIES 2015 International Conference, Intelligent Planning Towards Smart Cities, CITIES 2015, 227, 833-837. DOI: 10.1016/j.sbspro.2016.06.152

Chapin, F. S., \& Kaiser, J. (1979). Urban Land Use Planning. Chicago: University of Chicago Press.

Drabkin, H., \& Lichfield, D. (1980). Land Policy and Urban Growth. Oxford: Pegamon Press.

Giyarsih, S. R. (2001). Gejala Urban Sprawl Sebagai Pemicu Proses Densifikasi Permukiman di Daerah Pinggiran Kota (Urban Fringe Area). Jurnal $\quad$ PWK, 12(1), 40-45. Diakses dari http://download.garuda.ristekdikti.go.id/article.php?article=714482\&val=7386\&title=Gejala\%20Urban\%20Spraw1\%20Sebagai\%20 Pemicu\%20Proses\%20Densifikasi\%20Permukiman\%20di\%20Daerah\%20Pinggiran\%20Kota\%20Urban\%20Fringe\%20Area\%20 Kasus\%20Pinggiran\%20Kota\%20Yogyakarta

Irawan, B. (2005). Konversi Lahan Sawah: Potensi Dampak, Pola Pemanfaatannya, Dan Faktor Determinan, Forum Penelitian Agro Ekonomi, 23(1), 1-18. DOI: 10.21082/fae.v23n1.2005.1-18

Kalesaran, R. (2013). Analisa Faktor-Faktor yang Mempengaruhi Perumahan di Kota Manado, Jurnal IImiah Media Engineering, 3(3), 170184. Diakses dari https://media.neliti.com/media/publications/99064-ID-analisa-faktor-faktor-yang-mempengaruhi.pdf

Lambok, A. (2016). Faktor-Faktor yang Mempengaruhi Keputusan Petani dalam Mempertahankan Lahan Padi Sawah dari Konversi Menjadi Lahan Kelapa Sawit, Journal on Social Economic of Agriculture and Agribusiness, 5(12). Diakses dari http://bit.ly/Lambok 
Lestari, T. (2009). Dampak Konversi Lahan Pertanian Bagi Taraf Hidup Petani. Tesis Tidak Dipublikasikan, Institut Pertanian Bogor.

Pryor, R. (1968). Defining The Rural-Urban Fringe. Social Force, 47(2), 202-2015. DOI: 10.1093/sf/47.2.202

Rindarjono, M. G. (2007). Residental Mobility di Pinggiran Kota Semarang Jawa Tengah (Studi Kasus Kaum Miskin Kota di Kota Semarang). Indonesian Journal of Spatial and Regional Analysis, 21(2), 135-146. DOI: 10.23917/forgeo.v21i2.2358

Rupini, A. A., Dewi, N. A., \& Sueca, N. P. (2017). Implikasi Alih Fungsi Lahan Pertanian Pada Perkembangan Spasial Daerah Pinggiran Kota (Studi Kasus: Desa Batubulan, Gianyar. Undagi: Jurnal Ilmiah Jurusan Arsitektur Universitas Warmadewa, 5(2), 9-18. DOI: 10.22225/undagi.5.2.405.9-18

Sajogyo. (1992). Sosiologi Pedesaan. Yogyakarta: Gadjah Mada University Press.

Saputra, D.P.D., Rachmawati, R., \& Mei E.T.W. (2016). Penentuan Prioritas Lokasi Perumahan Di Kecamatan Kasihan Dengan Menggunakan Sistem Informasi Geografis, Jurnal Bumi Indonesia, 5(1), 1-10. Diakses dari http://lib.geo.ugm.ac.id/ojs/index.php/ji/article/view/257

Setiawan, B., Faryadi, E., \& Bachriadi, D. (1997). Reformasi Agraria: Perubahan Politik, Sengketa, dan Agenda Pembaruan Agraria di Indonesia. Jakarta: Konsorium Pembaruan Agraria bekerja sama dengan Lembaga Penerbit.

Sigit, A. (2019, Maret 18). Laju Pertumbuhan Penduduk di Solo Mendesak Dikendalikan. krjogja.com. Diakses dari: https://krjogja.com/web/news/read/94363/Laju_Pertumbuhan_Penduduk_di_Solo_Mendesak_Dikendalikan

Soegijoko. (1997). Perubahan Lahan Pertanian. Bandung: Pustaka Obor.

Wardana, W. (2007). Perilaku Pengembang Dalam Pemilihan Lokasi dan Pembebasan Lahan untuk Pembangunan Perumahan Sederhana. Yogyakarta: Andi Offset.

Wicaksono, R. B. (2012, Juni 22). Lahan Pertanian Jateng Berkurang 300.000 Hektare. Solopos.com. Diakses dari: https://www.solopos.com/lahan-pertanian-jateng-berkurang-300-000-hektare-195915

Wiguna, I. (2009). Hak-Hak Atas Tanah Pada Masa Bali Kuna Abad X dan XI Masehi. Denpasar: Udayana University Press.

Wulandari, F. (2017). Analisis Perubahan Penggunaan Lahan di Kecamatan Ngemplak Kabupaten Boyolali Tahun 2004 dan 2015. Tesis Tidak Dipublikasikan, Universitas Muhammadiyah Surakarta.

Yunus, H.S. (2000). Struktur Tata Ruang Kota. Yogyakarta: Pustaka Pelajar. 